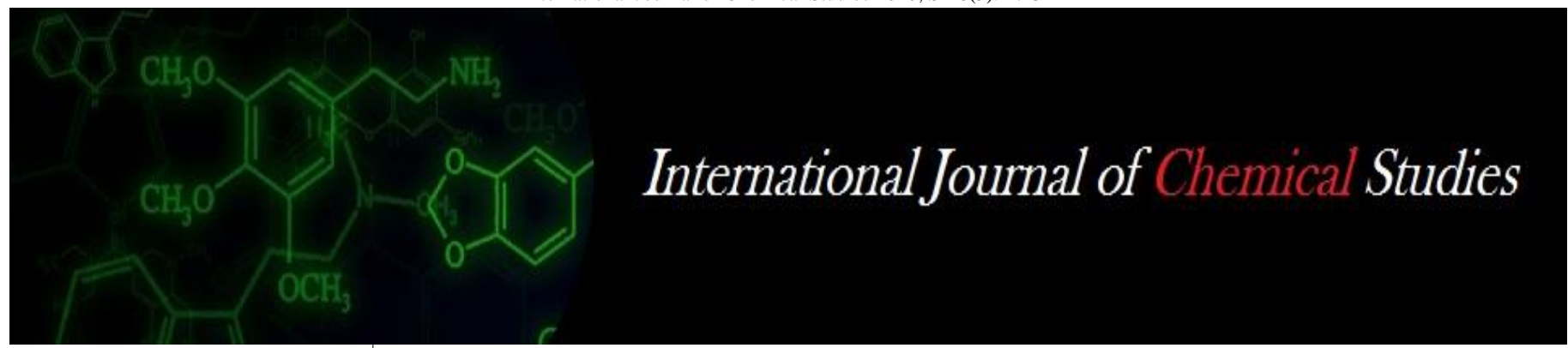

P-ISSN: 2349-8528

E-ISSN: 2321-4902

www.chemijournal.com

IJCS 2020; SP-8(5): 27-32

(C) 2020 IJCS

Received: 19-07-2020

Accepted: 24-08-2020

Dashrath Bhati

Post-Doctoral Fellow,

Department of Food and

Nutrition, College of Home

Science, GB Pant University of

Agriculture and Technology,

Pantnagar, Uttarakhand, India

Rita Singh Raghuvanshi

Dean and Professor,

Department of Food and

Nutrition, College of Home

Science, GB Pant University of

Agriculture and Technology,

Pantnagar, Uttarakhand, India

Corresponding Author:

Dashrath Bhati

Post-Doctoral Fellow,

Department of Food and

Nutrition, College of Home

Science, GB Pant University of

Agriculture and Technology,

Pantnagar, Uttarakhand, India

\section{Organoleptic properties and shelf life evaluation of snacks formulated by using cowpea}

\section{Dashrath Bhati and Rita Singh Raghuvanshi}

\author{
DOI: https://doi.org/10.22271/chemi.2020.v8.i5a.10365
}

\begin{abstract}
The present study investigated the organoleptic properties of traditional Indian snacks formulated by using cowpea and shelf life of these developed products for six months. Five products were formulated by using cowpea viz boondi, sev, papad, enrobed nuts and fried nuts. Bengal gram flour was used as control for comparing boondi, sev and papad with the cowpea products. However fried nuts prepared from cowpea was compared with black and yellow fried soybean. The sensory evaluation employed 15 trained panellists to assess colour, flavour, texture, taste, appearance and overall acceptability of all the products at nine point Hedonic rating scale. The sev, boondi, papad and enrobed nuts developed by using $100 \%$ cowpea flour were comparable with Bengal gram flour products and acceptable at 9 point hedonic rating scale. Similarly fried nut was also at par with soybean fried nuts. Among all these products four products i.e. boondi, sev, enrobed nuts and fried nuts were selected for further storage study. Boondi was found to be acceptable till 60 days of storage period. Non significant difference was observed in change for fried nut during storage period of 100 days in all the stored products. Change in flavour and taste was also non significant in enrobed nuts and fried nuts during storage period of 100 days.
\end{abstract}

Keywords: Cowpea, sensory quality, traditional Indian snacks, keeping quality and fried foods

\section{Introduction}

In present era snack foods have become a vital part of diets due to convenience offered by these food items. The term snack or snack food is difficult to define. The dictionary meaning of the snack is 'tit-bid', which is a meal in the broadest sense (Tettweiler, 1991) ${ }^{\text {[21]. Thus }}$ snacks are a food, which offer a light, meals. They are convenience to eat, involving no preparation time or efforts by consumer. The demand of snack foods is increasing day by day. Consequently, many types of snack foods are introduced into market place by manufacturer.

Pulses are important group of crops that provide high quality protein complementing cereal proteins pre-dominantly for vegetarian population of country like India. Cowpea, (Vigna unguiculata (L.) Walp) is one of the pulse crops which have been grown in India, since ancient times. It is a native of Africa, belongs to the family leguminosae (Goncalves et al., 2016; Lazaridi et al., 2016; Karapanos et al., 2017) ${ }^{[9,12,10]}$. This is the most versatile pulse crop because of its drought tolerance, suitability for multiple cropping systems and multiple uses such as green vegetable and food legumes. Besides all this cowpea is considered as an incredible source of many other health-promoting components, such as soluble and insoluble dietary fiber, phenolic compounds, minerals, and many other functional compounds, including B group vitamins (Liyanage et al., 2014; Mudryj et al., 2012) ${ }^{[13,15]}$. Thus, cowpea contributes greatly toward improving the quality of human health by offering a number of health benefits especially for developing countries like India. Pantnagar University has developed many early maturing grain cowpea varieties under pulse improvement programme aiming to increase per capita availability of legumes in the state. Grain cowpea varieties are high yielding, early maturing, well grown and fit in rice wheat cropping system in context of Uttarakhand, India wherein the lands are marginal with low productivity and rain fed agriculture (Pandey and Singh 2006) ${ }^{[16]}$.

In India most of the pulses are consumed as dal or as boiled salted preparation. Keeping the health benefits of cowpea in view there is great need to increase it's utilization as snack foods. This act will also help to release pressure on single crop. 
Improved production of cowpea is undoubtedly necessary to meet pulse demand but it is equally important to enhance diversified utilization of uncommon pulse like cowpea as snack food in Indian market.Keeping all this in view the present study deals with the formulation and sensory evaluation of cowpea snacks, and six months shelf life of these developed products.

\section{Methodology \\ Procurement of raw material: Cowpea variety Pant Lobia- 1 was procured from Vegetable Science Research Center, GB Pant University of agriculture and Technology, Pantnagar, Uttarakhand. The variety was selected on basis of recommendation of scientist from Vegetable Science Research Center. Other raw material such as black soybean, yellow soybean, Bengal gram flour, peanuts, refined oil, spices etc. were purchased from the local market of Pantnagar. All the raw materials were procured in a single lot.}

Primary processing: Cowpea, black and yellow soybean seeds and peanut seeds were cleaned thoroughly and made free from dust, dirt, spoilt grains, stone and other foreign matter. Cowpea seeds were divided into two parts and one part was ground into flour of mesh size of 70 and other part was kept as whole to prepare fried nuts.

Product development: On the basis of common and popular snacks in market as well as known to the general Indian population total five products were selected. These cowpea products were boondi, sev, papad, enrobed nuts and fried nuts. All these products were developed at the Department of Foods and Nutrition, College of Home Science, GB Pant University of Agriculture and Technology, Pantnagar, Uttarakhand.

a. Preparation of Boondi: This is a popular deep fat fried Indian traditional snack food prepared from the Bengal gram flour batter with suitable consistency and is fried in small bolls through perforated ladle (Thangum 1965) ${ }^{[22]}$. For the present study $50 \mathrm{gm}$ cowpea flour and $75 \mathrm{ml}$ water was mixed to form batter (CPB). After keeping aside for 30 minutes and it was poured through perforated ladle over hot oil to make small balls/ drops. Control was prepared by replacing cowpea flour from Bengal gram flour $(\mathrm{CoB})$.

b. Preparation of sev: It is small noodle shaped fried and crunchy snack popular in India made from Bengal gram flour dough containing pepper, chilli powder, turmeric and is relished for its texture and aroma. The thickness of these noodles varies. The hand operated stainless steel sev machine has six different disc templates. Control $(\mathrm{CoS})$ was prepared by using Bengal gram flour- $50 \mathrm{gm}$, oil- $5 \mathrm{ml}$, salt, spices, asafoetida powder, chilli powder and turmeric and water $20 \mathrm{ml}$. The dough was passed through the disc and deep fried. Cowpea sev (CPS) was prepared by replacing Bengal gram flour from cowpea flour.

c. Preparation of papad: Papad is a thin, circular shaped, fried wafer like product and normally made from pulse kernel flour with spices and other additives (Saxena et al. 1989) ${ }^{[20]}$. Control was prepared by using Bengal gram flour (CoP), oil, black pepper, salt, asafoetida powder, ajowan seeds, chilli powder and turmeric powder. Test sample was prepared by using cowpea flour (CPP).

d. Preparation of enrobed nuts: Roasted peanut were coated with Bengal gram flour containing salt, asafoetida powder and chat masala powder. Three types of enrobed nuts were prepared. Control $(\mathrm{CoE})$ was prepared by using Bengal gram flour $15 \mathrm{gm}, 1 \mathrm{gm}$ arrowroot powder, salt, asafoetida powder, chat masala and $50 \mathrm{gm}$ roasted peanuts. All these were mixed, $10 \mathrm{ml}$ water was added, mixed and fried. Two test enrobed nuts was prepare, one test sample was prepared by replacing Bengal gram flour (EA) and second one was prepared replacing arrowroot powder and Bengal gram flour completely (ECP).

e. Preparation of fried nuts: Control was prepared by using whole yellow soybean. The cowpea resembles with yellow soybean in appearance. The fried nuts were compared with both yellow (YFN) and black soybean (BFN). Soybean was soaked for 4 hours in lukewarm water and blanched for 20 minutes. Water was removed seeds were spread on blotting paper for 1 hour to remove extra water. After this seeds were fried, salt and chat masal was added to it. Cowpea fried nuts (CPFN) was prepared by soaking in lukewarm water for 1 hour and then blanched for 10 minutes then spread on blotting paper for 1 hour to remove extra water. After this seeds were fried and in last salt and chat masala was added.

Oil was changed after once used for frying of the developed products.

Sensory evaluation of the developed products: The organoleptic evaluation of the developed products was done at nine point Hedonic rating scale (from dislike extremely to like extremely). Coded samples were subjected to sensory evaluation after 12 hours of the production. Overall 13 semi trained panellist were evaluated the developed products. Scores were awarded for colour, texture, flavour, taste and overall acceptability.

On the bases of sensory evaluation four products were selected to study the storage of the developed products.

Storage of the developed products: On the basis of sensory evaluation four most acceptable products were stored for 100 days. All the selected products were packaged in flat pouch bag aluminium foil film liner moisture proof zipper sealed bags $(130 \mathrm{~mm} \times 205 \mathrm{~mm})$. The packets were of $75 \mathrm{gm}$ in weight and kept in a plastic container at ambient condition. At every $20^{\text {th }}$ day a fresh packet was opened for sensory and quality evaluation. During storage temperature and relative humidity on the day when the packets were opened for sensory evaluation was also recorded. Moisture content was evaluated at the interval of 20 days by using the standard method suggested by AOAC, (1999) ${ }^{[3]}$. Peroxide value was evaluated after the completion of the 100 days by the standard method of AOAC, (1999) ${ }^{[3]}$.

Statistical analysis: One way analysis of variance (ANOVA) was applied to determine significant differences between means, with the significance level taken at $(P<0.05)$. Statistical analysis of data was performed using WASP (Web Agri Stat Package) software version 2.0.

\section{Results and Discussion}

Sensory evaluation of the developed products: The mean sensory scores of the developed products are presented under table 1. The CPB boondi was at par at $0.05 \%$ level of significance with $\mathrm{CoB}$ boondi in all the sensory attributes. Texture of CPB boondi was more crisp then the CoB boondi. Cowpea sev (CPS) was comparable with $\operatorname{CoS}$ in all the 
sensory quality and was significantly better in texture. However, CoS sev had significantly high scores in terms of colour and appearance at $0.05 \%$ level of significance. Colour of the product also affects the appearance

papad prepared by cowpea (CPP) was acceptable however CoP papad was liked very much by the panel members. The texture of CoP papad liked by the panel members and significantly higher then CPP at 0.05 percent level of significance. The colour of CPP papad was also light brown and that affected the appearance of the products.

These all lead to decreased overall acceptability of CPP. However both the variations of papad were liked by the panel members.

Enrobed nut prepared by using $100 \%$ cowpea (ECP) was at par with Bengal gram flour enrobed nuts. The enrobed nuts prepared from cowpea and arrowroot powder (EA) was hard texture then ECP and CoE enrobed nuts. Overall acceptability of ECP had higher scores by the panel members due to its crunchy texture. Soybean fried nuts (YNF) and black soybean nuts (BFN) were varied significantly in terms of colour and appearance. The cowpea nuts (LFN) was at par with YNF fried nuts in terms of all the sensory parameters. All the three products were acceptable at nine point hedonic rating scale.

Bhagirathi et al., $1992^{[7]}$ had developed papad by using two cowpea verities and black gram and reported that the cowpea papad were placed in liked very much and liked extremely categories. The quality of various products made from cowpea flour in different parts of world which are dependent on the functionality of cowpea flour; as influenced by processing technique, cowpea variety, particle size distribution of the flour, ingredients and the hydration pattern of the flour mixture.(Appiah et al., 2011; Apea-Bah et al., 2016) ${ }^{[5,4]}$.

Several other studies on thereputic aspect of cowpea revels that the consumption of cowpea exerts protective effects against the development of several chronic diseases, such as gastrointestinal disorders (Trehan et al., 2015) ${ }^{\text {[24] }}$, diabetes (Rotimi et al, 2013; Barnes et al., 2015) ${ }^{[19,6]}$ and several types of cancer (Chon, 2013; Khalid and Elharadallou, 2013) $[8,11]$. With this, cowpea is also helpful in weight reduction (Perera et al., 2016) ${ }^{[17]}$, improve digestion and strengthen blood circulation (Trehan et al., 2015) ${ }^{[24]}$.

Among all these five products four products i.e. boondi, sev, enrobed nuts and fried nuts were selected for further storage study. Papad had scored least in terms of appearance and hence it was dropped for further study.

\section{Sensory quality of the selected products during storage}

Sensory evaluation of the products offers the opportunity to obtain a complete analysis the changes in the various properties of food as perceived by human senses during storage. Table 2 (a) and (b) depicts the mean sensory scores of the stored products i.e. boondi (CPB); sev (CPS) and enrobed nuts $(\mathrm{ECP})$; fried nuts $(\mathrm{CPFN})$ respectively.

$\mathrm{CPB}$ boondi was found to be acceptable as indicated by the score above 6 for all the attributes till 100 days of storage period. However significant decline was observed in all the attributes except colour of the boondi after 60 days of storage and slight rancid flavour was stated developing in the boondi. In CPS sev significant change in flavour and taste was developed at $60^{\text {th }}$ and $80^{\text {th }}$ day of storage respectively. No significant difference was observed during 100 days of storage of enrobed nuts (ECP).

However bitter taste was started developing at $80^{\text {th }}$ day of storage and that effected the taste of the product. Non significant difference was observed in change in colour during storage period of 100 days in all the stored products. Change in flavour and taste was also non significant in enrobed nuts and fried nuts during storage period of 100 days.

Temperature and relative humidity: Temperature and relative humidity was also recorded and shown in figure1 (a). It was observed that at the $20^{\text {th }}$ and $40^{\text {th }}$ day of storage the humidity was higher. This also affected the moisture content of the products. After opening the packets the moisture was absorbed by the products. Due to this the crunchy texture of the products was lost and products became slightly soggy. The maximum effect was seen on the boondi (CPB) and sev (CPS).

\section{Moisture content during storage period:}

Moisture per cent was analysed at the interval of 20 days and presented in figure 1 (b). Moisture content during storage of the fried snacks can lead to quality degradation and sensory attributes such as texture and finally result in shorter shelf life and rejection of the products (Tiwari, et al. 2011) ${ }^{[23]}$.

\section{Peroxide value}

Figure (c) depicts the peroxide value after 100 days of storage. The maximum peroxide value was recorded in enrobed nuts $(3.53 \mathrm{mEq} / \mathrm{kg})$ followed by boondi $(2.68$ $\mathrm{mEq} / \mathrm{kg})$, Fried nuts $(1.47 \mathrm{mEq} / \mathrm{kg})$ and $\operatorname{Sev}(1.25 \mathrm{mEq} / \mathrm{kg})$. Akinoso, et al, $2010^{\left[1^{`}\right]}$ conducted a study on sesame (Sesamum indicum $\mathrm{L}$ ) seeds processing for oil extraction and investigated effects of initial moisture content, roasting duration and temperature on initial peroxide value and oxidative stability. The study concluded that increase in roasting temperature and duration increased the oxidative stability and a reverse was observed with initial moisture content. High moisture content reduced the quality and storage life while heat treatment increased both the initial quality and storage life of the mechanically expressed oil. The enrobed nuts were formulated by coating peanuts which are known to be rich in fats. With this before enrobing heat was applied to roast it and then water was added for enrobing the batter followed by frying in last. Hence higher the amount of fat and added moisture content may be responsible for increased peroxide value during storage of the enrobed. When the boondi were placed in hot oil, the moisture content fell rapidly. The outer surface "crust" gets dried, providing a diffusion gradient, and the moisture inside the product is converted to steam, causing a pressure gradient. As this continues, the area surrounding the moisture escape site dries out and loses its hydrophilicity. Oil may then adhere to the product and enter into the product through the pores and also damaged areas (Ravi and Susheelamma, 2005) ${ }^{[18]}$. The acceptance of food product is based on the extent to which deterioration has occurred. Oxidative rancidity is a main reason of off flavour and degradation during storage of fried foods. This also leads to loss of nutritional quality and cause of concern for food safety. The oxidized fats in very high dosage have been shown to have toxic effects (Allen \& Hamilton, 1983) ${ }^{[2]}$. 
Table 1: Mean sensory scores of the products developed by using cowpea

\begin{tabular}{|c|c|c|c|c|c|c|c|c|c|c|c|c|c|c|c|c|c|c|c|c|c|c|}
\hline & \multicolumn{4}{|c|}{ Boondi } & \multicolumn{4}{|c|}{ Sev } & \multicolumn{4}{|c|}{ Papad } & \multicolumn{5}{|c|}{ Enrobed nuts } & \multicolumn{5}{|c|}{ Fried Nuts } \\
\hline & CoB & CPB & CV & CD & $\mathrm{CoS}$ & CPS & CV & CD & CoP & CPP & CV & CD & CoE & \begin{tabular}{l|l} 
EA & \\
\end{tabular} & ECP & CV & CD & YFN & BFN & \begin{tabular}{|l|} 
CPFN \\
\end{tabular} & CV & CD \\
\hline Colour & $8.23^{\mathrm{a}} \pm 0.246$ & $7.83^{\mathrm{a}} \pm 0.386$ & 7.837 & $\mathrm{p}>0.05$ & $\begin{array}{c}8.58^{\mathrm{a}} \pm \\
0.229\end{array}$ & $7.58^{\mathrm{b}} \pm 0.229$ & 97.460 & 0.765 & $8.25^{\mathrm{a}} \pm 0.218$ & $7.58^{\mathrm{b}} \pm 0.149$ & 7.928 & 0.564 & $7.87 \pm 0.192$ & $7.57 \pm 0.161$ & $7.70 \pm 0.194$ & $|8.427|$ & $p>0.05$ & $7.89^{\mathrm{a}} \pm 0.170$ & $7.63 a b \pm 0.113$ & $7.16 \mathrm{~b} \pm 0.257$ & 710.806 & 0.538 \\
\hline Flavour & $8.00^{\mathrm{a}} \pm 0.246$ & $7.92^{\mathrm{a}} \pm 0.336$ & 9.628 & $p>0.05$ & $\begin{array}{c}7.92^{\mathrm{a}} \\
\pm 0.288 \\
\end{array}$ & $\begin{array}{c}7.50^{\mathrm{a}} \\
\pm 0.151 \\
\end{array}$ & $9.138 \mathrm{f}$ & $p>0.05$ & $\begin{array}{c}7.92^{\mathrm{a}} \\
\pm 0.229 \\
\end{array}$ & & 11.677 & $|p>0.05|$ & $7.90 \pm 0.170$ & $7.57 \pm 0.128$ & $8.00 \pm 0.189$ & 7.559 & $p>0.05$ & $8.11 \mathrm{a} \pm 0.105$ & $7.68 \mathrm{a} \pm 0.154$ & $7.21 \mathrm{~b} \pm 0.271$ & 8.977 & 0.453 \\
\hline Texture & $7.75^{\mathrm{a}} \pm 0.305$ & $8.17^{\mathrm{a}} \pm 0.366$ & 5.940 & $\mid p>0.05$ & $\begin{array}{c}7.75^{\mathrm{a}} \\
\pm 0.351 \\
\end{array}$ & $\begin{array}{c}8.08^{\mathrm{a}} \\
\pm 0.229 \\
\end{array}$ & $9.585 \mathrm{p}$ & $p>0.05$ & $17^{\mathrm{a}} \pm 0.112$ & $42^{b} \pm 0.149$ & 5.641 & 0.395 & $8.27 a \pm 0.153$ & $7.60 \mathrm{~b} \pm 0.1637$ & $7.97 \mathrm{ab} \pm 0.186$ & 7.455 & 0.443 & $7.89 a \pm 0.130$ & $7.63 a b \pm 0.205$ & $7.08 \mathrm{~b} \pm 0.302$ & 12.753 & 0.632 \\
\hline Taste & $7.88^{\mathrm{a}} \pm 0.315$ & $7.92^{\mathrm{a}} \pm 0.379$ & 7.260 & $p>0.05$ & $\begin{array}{c}8.08^{\mathrm{a}} \\
\pm 0.229 \\
\end{array}$ & $\begin{array}{c}7.92^{\mathrm{a}} \\
\pm 0.193 \\
\end{array}$ & $8.286 \mathrm{p}$ & $p>0.05$ & $\begin{array}{c}8.17^{\mathrm{a}} \\
\pm 0.207 \\
\end{array}$ & \begin{tabular}{|c|}
$7.58^{\mathrm{a}}$ \\
\pm 0.229 \\
\end{tabular} & 8.945 & $p>0.05$ & $8.27 \mathrm{a} \pm 0.248$ & $7.53 \mathrm{~b} \pm 0.1727$ & $7.93 \mathrm{ab} \pm 0.12$ & 8.026 & 0.475 & $8.00 \pm 0.202$ & $7.74 \pm 0.168$ & $7.34 \pm 0.311$ & 12.445 & $p>0.05$ \\
\hline Appearance & $7.83^{\mathrm{a}} \pm 0.322$ & $7.67^{\mathrm{a}} \pm 0.376$ & 7.612 & $p>0.05$ & $8.25^{\mathrm{a}} \pm 0.179$ & $7.63^{\mathrm{b}} \pm 0.186$ & 6.881 & 0.491 & $8.08^{\mathrm{a}} \pm 0.149$ & $6.83^{b} \pm 0.112$ & 4.288 & \begin{tabular}{|l|}
0.287 \\
\end{tabular} & $8.03 \pm 0.260$ & $7.57 \pm 0.128$ & $7.83 \pm 0.205$ & 9.167 & $p>0.05$ & $8.00 \mathrm{a} \pm 0.153$ & $7.89 \mathrm{a} \pm 0.169$ & $7.26 \mathrm{~b} \pm 0.214$ & 8.627 & 0.438 \\
\hline
\end{tabular}

Table 2(a): Mean sensory scores of Boondi and Sev during storage

\begin{tabular}{|c|c|c|c|c|c|c|c|c|c|c|c|c|c|c|c|c|}
\hline & \multicolumn{8}{|c|}{ Boondi (CPB) } & \multicolumn{8}{|c|}{ Sev (CPS) } \\
\hline & $\mathbf{0}$ & 20 & 40 & 60 & 80 & 100 & CV & CD & $\mathbf{0}$ & 20 & 40 & 60 & 80 & 100 & CV & CD \\
\hline & $23^{\mathrm{a}} \pm 0.166$ & $23^{\mathrm{a}} \pm 0.122$ & $.19^{\mathrm{a}} \pm 0.133$ & $15^{\mathrm{a}} \pm 0.191$ & $.92^{\mathrm{a}} \pm 0.137$ & $88^{\mathrm{a}} \pm 0.228$ & 7.748 & $p>0.05$ & $46^{\mathrm{a}} \pm 0.144$ & $.42^{\mathrm{a}} \pm 0.137$ & $8.38^{\mathrm{a}} \pm 0.171$ & $8.15^{\mathrm{a}} \pm 0.1$ & $8.04^{\mathrm{a}} \pm 0.1$ & $7.92^{\mathrm{a}} \pm 0.211$ & 7.681 & $p>0.05$ \\
\hline & & $7.92^{\mathrm{a}} \pm 0.246$ & $7.73^{\mathrm{a}} \pm 0.216$ & & & $35^{b} \pm 0.236$ & 11.402 & 0.660 & $77^{\mathrm{a}} \pm 0.122$ & $8.77^{\mathrm{a}} \pm 0.092$ & $8.73^{\mathrm{a}} \pm 0.108$ & & & ${ }^{c} \pm 0.077$ & 3.852 & 0.257 \\
\hline Texture & $5^{\mathrm{a}} \pm 0.154$ & $7.81^{\mathrm{a}} \pm 0.286$ & $7.65^{\mathrm{a}} \pm 0.207$ & $7.38^{\mathrm{a}} \pm 0.180$ & $6.69^{b} \pm 0.263$ & $.65^{b} \pm 0.249$ & 11.409 & 0.657 & $8.65^{\mathrm{a}} \pm 0.131$ & $8.62^{\mathrm{a}} \pm 0.129$ & $8.54^{\mathrm{a}} \pm 0.120$ & $8.42^{\mathrm{a}} \pm 0$ & $8.35^{\mathrm{ab}} \pm 0.131$ & $8.08^{\mathrm{b}} \pm 0.077$ & 5.206 & 0.345 \\
\hline Taste & & $8.04^{\mathrm{a}} \pm 0.132$ & $7.62^{\mathrm{a}} \pm 0.180$ & & $6.62^{\mathrm{b}} \pm 0.368$ & $6.19^{b} \pm 0.286$ & 11.246 & 0.647 & & $8.42^{\mathrm{a}} \pm 0.137$ & $8.35^{\mathrm{a}} \pm 0.191$ & $8.23^{\mathrm{ab}} \pm 0.122$ & $7.96^{\mathrm{b}} \pm 0.120$ & $7.88^{\mathrm{b}} \pm 0.140$ & 5.664 & 0.365 \\
\hline & & & & & & & & & & & & & & & 8.224 & $p>0.05$ \\
\hline Over all Acceptability & $7.96^{\mathrm{a}} \pm 0.120$ & $7.88^{\mathrm{a}} \pm 0.162$ & $7.81^{\mathrm{a}} \pm 0.208$ & $7.77^{\mathrm{a}} \pm 0.156$ & $6.65^{\mathrm{b}} \pm 0.386$ & $6.62^{b} \pm 0.241$ & 11.169 & 0.653 & $8.69^{\mathrm{a}} \pm 0.175$ & $8.62^{\mathrm{a}} \pm 0.129$ & $8.62^{\mathrm{a}} \pm 0.129$ & $8.35^{\mathrm{ab}} \pm 0.131$ & $8.04^{\mathrm{bc}} \pm 0.089$ & $7.92^{\mathrm{c}} \pm 0.077$ & 5.390 & 0.354 \\
\hline
\end{tabular}

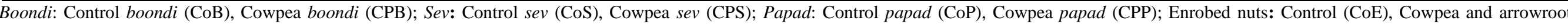
powder enrobed nuts (EA), Cowpea flour enrobed nuts (ECP); Fried nuts: Whole yellow soybean (YFN), black soybean (BFN) and Cowpea fried nuts (CPFN)

\pm Standard deviation Different alphabets in superscript in each row show significant difference between values CV- Coefficient of variation, CD-critical difference

Table 2(b): Mean sensory scores of enrobed nuts and fried nuts during storage

\begin{tabular}{|c|c|c|c|c|c|c|c|c|c|c|c|c|c|c|c|c|}
\hline & \multicolumn{8}{|c|}{ Enrobed (ECP) } & \multicolumn{8}{|c|}{ Fried Nuts (CPFN) } \\
\hline & $\mathbf{0}$ & 20 & 40 & 60 & 80 & 100 & CV & CD & $\mathbf{0}$ & 20 & 40 & 60 & 80 & 100 & CV & CD \\
\hline Colour & $8.54^{\mathrm{a}} \pm 0.144$ & $8.46^{\mathrm{a}} \pm 0.183$ & $8.46^{\mathrm{a}} \pm 0.144$ & $8.38^{\mathrm{a}} \pm 0.171$ & $8.27^{\mathrm{a}} \pm 0.216$ & $8.12^{\mathrm{a}} \pm 0.278$ & 8.343 & $p>0.05$ & $8.38^{\mathrm{a}} \pm 0.140$ & $8.31^{\mathrm{a}} \pm 0.175$ & $8.23^{\mathrm{a}} \pm 0.263$ & $8.23^{\mathrm{a}} \pm 0.201$ & $8.15^{\mathrm{a}} \pm 0.154$ & $8.19^{\mathrm{a}} \pm 0.192$ & 8.690 & $p>0.05$ \\
\hline Flavour & $8.46^{\mathrm{a}} \pm 0.144$ & $8.42^{\mathrm{a}} \pm 0.183$ & $8.35^{\mathrm{a}} \pm 0.249$ & $8.38^{\mathrm{a}} \pm 0.241$ & $7.96^{\mathrm{ab}} \pm 0.120$ & $7.69^{\mathrm{b}} \pm 0.208$ & 8.641 & 0.557 & $8.46^{\mathrm{a}} \pm 0.243$ & $8.42^{\mathrm{a}} \pm 0.178$ & $8.42^{\mathrm{a}} \pm 0.225$ & $8.37^{\mathrm{a}} \pm 0.175$ & $8.19^{\mathrm{a}} \pm 0.106$ & $8.15^{\mathrm{a}} \pm 0.296$ & 9.238 & $p>0.05$ \\
\hline Texture & $8.62^{\mathrm{a}} \pm 0.140$ & $8.54^{\mathrm{a}} \pm 0.183$ & $8.54^{\mathrm{a}} \pm 0.144$ & $8.23^{\mathrm{a}} \pm 0.224$ & $8.12^{\mathrm{a}} \pm 0.213$ & $8.04^{\mathrm{a}} \pm 0.230$ & 7.551 & $p>0.05$ & $8.54^{\mathrm{a}} \pm 0.144$ & $8.58^{\mathrm{a}} \pm 0.137$ & $8.42^{\mathrm{a}} \pm 0.195$ & $8.38^{\mathrm{a}} \pm 0.129$ & $8.27^{\mathrm{a}} \pm 0.184$ & $8.23^{\mathrm{a}} \pm 0.122$ & 6.672 & $p>0.05$ \\
\hline Taste & $8.62^{\mathrm{a}} \pm 0.129$ & $8.65^{\mathrm{ab}} \pm 0.131$ & $8.62^{\mathrm{ab}} \pm 0.140$ & $8.46^{\mathrm{ab}} \pm 0.183$ & $8.15^{\mathrm{bc}} \pm 0.154$ & $7.81^{\mathrm{c}} \pm 0.223$ & 7.124 & 0.469 & $8.69^{\mathrm{a}} \pm 0.133$ & $8.62^{\mathrm{a}} \pm 0.140$ & $8.54^{\mathrm{a}} \pm 0.144$ & $8.54^{\mathrm{a}} \pm 0.144$ & $8.50^{\mathrm{a}} \pm 0.160$ & $8.46^{\mathrm{a}} \pm 0.215$ & 6.762 & $\mathrm{p}>0.05$ \\
\hline Appearance & $8.46^{\mathrm{a}} \pm 0.144$ & $8.42^{\mathrm{a}} \pm 0.159$ & $8.35^{\mathrm{a}} \pm 0.222$ & $8.23^{\mathrm{a}} \pm 0.166$ & $8.12^{\mathrm{a}} \pm 0.213$ & $8.08^{\mathrm{a}} \pm 0.265$ & 8.382 & $p>0.05$ & $8.62^{\mathrm{a}} \pm 0.140$ & $8.58^{\mathrm{a}} \pm 0.137$ & $8.54^{\mathrm{a}} \pm 0.144$ & $8.42^{\mathrm{a}} \pm 0.137$ & $8.38^{\mathrm{a}} \pm 0.140$ & $8.42^{\mathrm{a}} \pm 0.137$ & 5.626 & $\mathrm{p}>0.05$ \\
\hline Over all Acceptability & $8.58^{\mathrm{a}} \pm 0.137$ & $8.50^{\mathrm{a}} \pm 0.160$ & $8.46^{\mathrm{a}} \pm 0.215$ & $8.35^{\mathrm{a}} \pm 0.131$ & $8.19^{\mathrm{a}} \pm 0.223$ & $8.08^{\mathrm{a}} \pm 0.178$ & 7.554 & $p>0.05$ & $8.62^{\mathrm{a}} \pm 0.140$ & $8.58^{\mathrm{a}} \pm 0.137$ & $8.54^{\mathrm{a}} \pm 0.215$ & $8.52^{\mathrm{a}} \pm 0.212$ & $8.50^{\mathrm{a}} \pm 0.139$ & $8.46^{\mathrm{a}} \pm 0.144$ & 7.299 & $p>0.05$ \\
\hline
\end{tabular}

\pm Standard deviation Different alphabets in superscript in each row show significant difference between values

CV- Coefficient of variation, CD-critical difference 

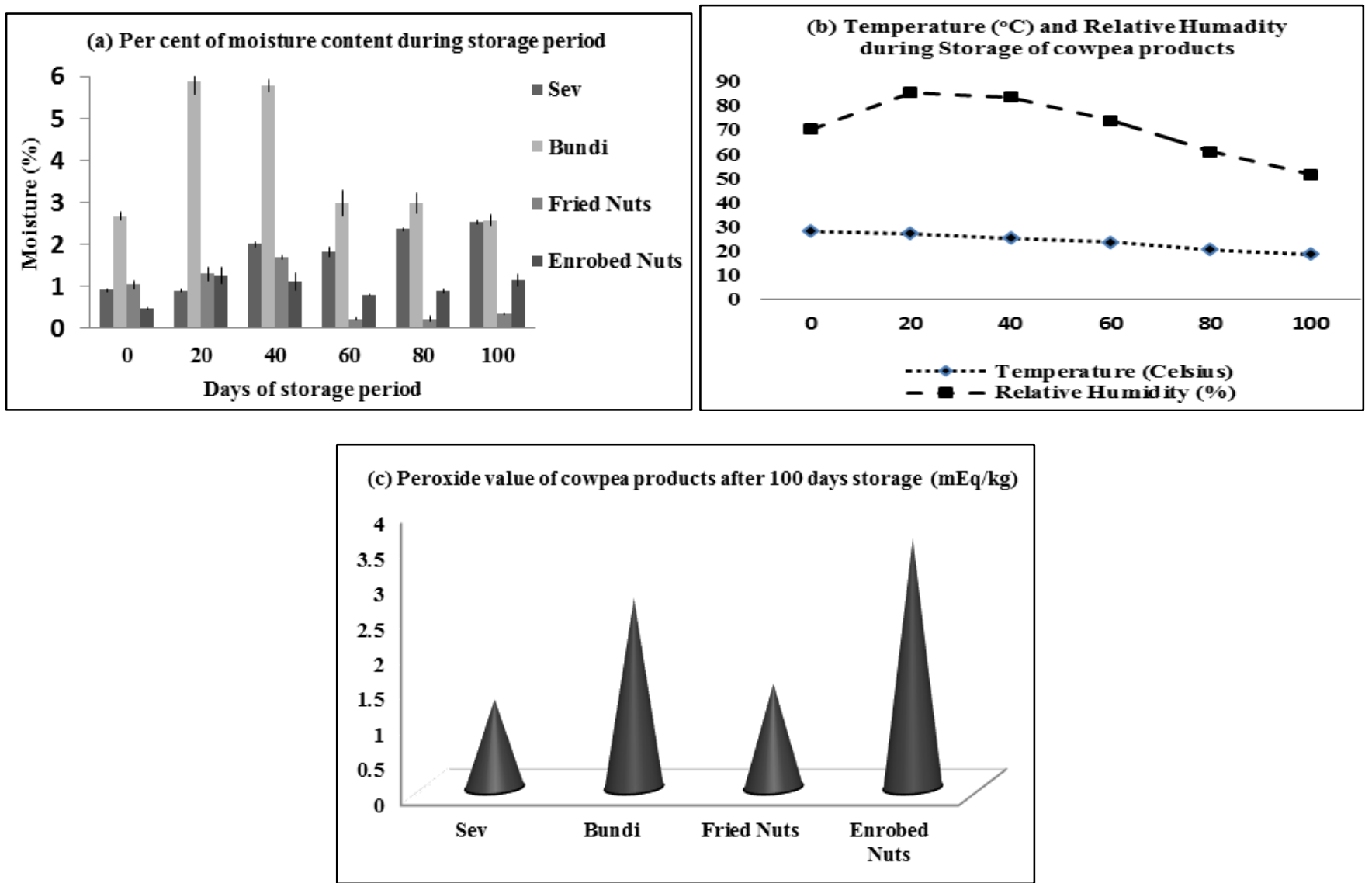

Fig 1: (a) Temperature and relative humidity (b) Per cent moisture content during storage period and (c) Peroxide value in products after 100 days of storage period.

\section{Conclusion}

Cowpea flour and seed both can be utilized as snacks and may be helpful to cater the need of snack market in India. Besides this boondi prepared by cowpea may also be utilized as sweet $l a d d u$ formation. Other sweet products such as laddu, barfi etc. which are prepared traditionally by using Bengal gram flour needed to be explored by using cowpea flour. Cowpea could be best alternative of Bengal gram flour and the snacks prepared by using it.

\section{Acknowledgement}

The authors are thankful to UGC's Dr. Dr. S. Radhakrishnan Post Doctoral Fellowship for providing financial support to conduct this work. Authors are also grateful to all the reviewers for his valuable comments to improve the quality of paper.

\section{References}

1. Akinoso R, Aboaba SA, Olayanju TMA. Effects of moisture content and heat treatment on peroxide value and oxidative stability of un-refined sesame oil. African Journal of Food, Agriculture, Nutrition and Development. 2010; 10(10):4268-4285.

2. Allen JC, Hamilton RJ. Rancidity in foods, (Eds.) Applied Science Publishers, London, New York, 1983.

3. AOAC. Official methods of analysis of the association of official analytical chemists (15th ed.). Arlington, VA, USA, 1999.

4. Apea-Bah FB, Minnaar A, Bester MJ, Sorghum-cowpea. composite porridge as a functional food, Part II: Antioxidant properties as affected by simulated in vitro gastrointestinal digestion. Food Chemistry. 2016; 197(Part A):307-315.
5. Appiah F, Asibuo J, Kumah P. Physicochemical and functional properties of bean flours of three cowpea (Vigna unguiculata L. Walp) varieties in Ghana. African Journal Food Science. 2011; 5(2):100-104.

6. Barnes M, Uruakpa F, Udenigwe C. Influence of cowpea (Vigna unguiculata) peptides on insulin resistance. J Nutr Health Food Sci. 2015; 3:1-3.

7. Bhagirathi L, Urooj A, Puttaraj S. Utilization of cowpea in the preparation of papad. Journal of Food quality. 1992; 15:349-355.

8. Chon S-U. 2013. Total polyphenols and bioactivity of seeds and sprouts in several legumes. Curr PharmDes. 2013; 19:6112-6124.

9. Goncalves A, Goufo P, Trindade H, Rosa EA, Ferreira L, Dominguez-peris R et al. Cowpea (Vigna unguiculata L. Walp), A renewed multipurpose crop for a more sustainable Agri-food system: nutritional advantages and constraints. J Sci Food Agric. 2016; 96:2941-2951.

10. Karapanos I, Papandreou A, Makrogianni D, Fernandez JA, Rosa E, Ntatsi G et al. Cowpea fresh pods - a new legume for the market:assessment of their quality and dietary characteristics of 37 cowpea accessions grown in southern Europe. J Sci Food Agric2017; 97:4343-4352.

11. Khalid II, Elharadallou SB. Functional properties of cowpea (Vigna ungiculata L. Walp), and Lupin (Lupinus termis) flour and protein isolates. J Nutr Food Sci. 2013; 3:1-6.

12. Lazaridi E, Ntatsi G, Savvas D, Bebeli PJ. Diversity in cowpea (Vigna unguiculata (L.) Walp.) local populations fromGreece. Genet Resour Crop Evol. 2016; 64:15291551.

13. Liyanage R, Perera OS, Wethasinghe $\mathrm{P}$, Jayawardana BC, Vidanaarachchi JK, Sivaganesan R et al. Nutritional 
properties and antioxidant content of commonly consumed cowpea cultivars in Sri Lanka. J Food Legum Indian J Pulses Res. 2014; 27:215-217.

14. Moutaleb OH, Amadou I, Amza T, Zhang M. Physicofunctional and sensory properties of cowpea flour based recipes (akara) and enriched with sweet potato. J Nutr Health Food Eng. 2017; 7(4):325-330. DOI: 10.15406/jnhfe. 2017.07.00243

15. Mudryj AN, Yu N, Hartman TJ, Mitchell DC, Lawrence FR, Aukema HM et al. Pulse consumption in Canadian adults influences nutrient intakes. $\mathrm{Br} \mathrm{J}$ Nutr. 2012; 108:27-36.

16. Pandey B, Singh JV. Combining ability for yield over environment in cowpea [Vigna unguiculata (L.) walp.]. Legume Research. 2006, 33(3):190-195.

17. Perera O, Liyanage R, Jayawardana BC, Vidanarachchi JK, Fernando P, Sivaganesan R et al. Modulating effects of cowpea incorporated diets on serum lipids and serum antioxidant activity in Wistar rats. J Natl Sci Found Sri Lanka. 2016; 44:69.

18. Ravi R, Susheelamma NS. Simultaneous Optimization of a Multiresponse System by Desirability Function Analysis of Boondi-making: A Case Study. Journal of Food Science. 2005; 70(8): 539-547.

19. Rotimi SO, Olayiwola I, Ademuyiwa O, Adamson I. Improvement of diabetic dyslipidemia by legumes in experimental rats. Afr J Food Agric Nutr Dev. 2013; 13:1-18.

20. Saxena AK, Kulkarni SG, Mana NJK, Berry SK. Studies on the blends of different pulses (Bengal gram, Green gram, Lentils and Arhar) in the preparation of North Indian spiced papads. J Food Sci. Technol. 1989; 26(3):133-136.

21. Tettweiller P. Snack food world wide. Food Technology. 1991; 45(2):58.

22. Thangum E. Philips. Modern cookery for teaching and the trade. Vol. I. India: Orient Longman, 1965, 381.

23. Tiwari U, Gunasekaran MA, Jaganmohan R, Alagusundaram K., Tiwari BK. Quality characteristic and shelf life studies of deep-fried snack prepared from rice broken and legumes by-product. Food Bioprocess Technology. 2011; 7:1172-1178.

24. Trehan I, Benzoni NS, Wang AZ, Bollinger LB, Ngoma TN, Chimimba UK et al. Common beans and cowpeas as complementary foods to reduce environmental enteric dysfunction and stunting in Malawian children: study protocol for two randomized controlled trials. Trials. $2015 ; 16: 520$. 